\title{
Kedudukan Hukum Anak Perusahaan Badan Usaha Milik Daerah
}

\author{
Sigit Somadiyono \\ Magister Hukum Universitas Batanghari \\ Jln. Slamet Riyadi Broni Kota Jambi \\ Correspondence email: sigit.somadiyono@unbari.ac.id
}

\begin{abstract}
Abstrak. Anak perusahaan adalah perusahaan yang lahir disebabkan oleh terjadinya pengalihan atau penyertaan saham mayoritas oleh perusahaan lain atau disebut induk perusahaan. Tidak ada pengaturan yang terkait anak perusahaan pada peraturan perundang-undangan terkait perusahaan ataupun tentang Badan Usaha Milik Daerah. Hal tersebut menyebabkan terjadinya simpang siur tentang kedudukan anak perusahaan Badan Usaha Milik Daerah khususnya ketidakjelasan kedudukan keuangan negara pada anak perusaaan. Permasalahan dalam penelitian ini adalah Bagaimana status hukum kepemilikan anak perusahaan Badan Usaha Milik Daerah? Dan Bagaimana tanggungjawab perusahaan induk Badan Usaha Milik Daerah terhadap anak perusahaannya? Tujuan penelitian ini adalah untuk mengetahui status hukum dari anak perusahaan dan tanggungjawab Badan Usaha Milik Daerah sebagai induk perusahaan. Metode penelitian yang digunakan adalah yuridis normatif yang menganalisa dari peraturan perundang-undangan dan teori para yuris. Dari hasil penelitian didapat fakta bahwa walaupun berstatus anak perusahaan Badan Usaha Milik Daerah tapi anak perusahaan tersebut bukanlah milik Pemerintah Daerah melainkan berstatus swasta atau privat, sehingga tiada hubungan hukum khusus yang mengikat antara Pemerintah Daerah sebagai pemegang saham Badan Usaha Milik Daerah dengan anak perusahaan yang dimiliki Badan Usaha Milik Daerah. Tanggungjawab Badan Usaha Milik Daerah selaku induk perusahaan dengan anak perusahaan hanya sebatas hubungan pemegang saham dan perseroan sebagaimana diatur dalam Undang-Undang Nomor 40 Tahun 2007 tentang Perseroan Terbatas.
\end{abstract}

Kata kunci: Badan Usaha Milik Daerah, Anak Perusahaan, hukum perusahaan.

\begin{abstract}
Subsidiary is a company that was born due to the transfer or participation of majority shares by another company or it is called the parent company. There are no regulations related to subsidiaries in the laws and regulations related to companies or regarding Regional Owned Enterprises. This has resulted in confusion regarding the position of the regional-owned company subsidiaries, especially the unclear position of state finances in the subsidiary companies. The problem in this research is what is the legal status of ownership of a regional-owned company subsidiary? And what is the responsibility of the holding company of a Regionally Owned Company to its subsidiaries? The purpose of this study was to determine the legal status of the subsidiary and the responsibilities of the Regional Owned Company as the holding company. The research method used is normative juridical analysis of the laws and regulations and the theory of the jurists. From the results of the research, it is found that even though the status is a subsidiary of a Regional Owned Enterprise, the subsidiary is not owned by the Regional Government but has a private or private status, so that there is no special binding legal relationship between the Regional Government as a shareholder of a Regional Owned Enterprise and its owned subsidiary Regional owned enterprises. The responsibility of a Regional Owned Company as the holding company with its subsidiary is limited to the relationship between the shareholders and the company as stipulated in Law Number 40 of 2007 concerning Limited Liability Companies.
\end{abstract}

Keywords: Regional Owned Enterprises, Subsidiaries, company law

\section{PENDAHULUAN}

Perkembangan ekonomi suatu negara tidak hanya ditopang oleh pendapataan pajak dan/atau kekayaan alamnya saja, tetapi ikut ditopang dengan keberadaan perusahaan milik swasta maupun perusahaan milik pemerintah. Perkembangan perusahaan milik pemerintah atau state owned enterprises (SOEs) dalam pengaruh ekonomi diduniatelah meningkat selama satu dekade terakhit. ${ }^{1}$ Dasar pendirian Perusahaan milik pemerintah di Indonesia adalah pada Pasal 33 Ayat (2) Undang-Undang Dasar tahun 1945 serta peraturan perundang-undangan lainnya.

Perusahaan milik pemerintah di Indonesia dibagi atas tiga bentuk yaitu (1) Badan Usaha Milik Negara (BUMN); (2) Badan Usaha Milik Daerah (BUMD); dan (3) Badan Usaha Milik Desa (BUMDes). Perusahaan milik pemerintah merupakan perusahaan publik yang berbadan hukum sehingga umumnya berbentuk Perseroan Terbatas sebagaimana diatur dalam Undang-Undang Nomor 40 Tahun 2007 tentang Perseroan Terbatas.

Perusahaan milik pemerintah pada perkembangannya terdiri dari Perusahaan Umum (Perum)/Perusahaan Umum Daerah (Perumda) dan Perusahaan Perseroan (Persero)/Perusahaan Perseroan Daerah (Perseroda). Perbedaan signifikan antaran Perum/Perumda dengan Persero/Perseroda adalah terletak pada jumlah saham yang dimiliki oleh pemerintah, yaitu Perum/Perumda semua sahamnya dimiliki oleh pemerintah pusat atau satu pemerintah Daerah yaitu

${ }^{1}$ Sigit Somadiyono, Prinsip Kepemilikan dan Kemandirian Badan Usaha Milik Daerah dalam Kaitannya Sebagai Perusahaan Milik Pemerintah, Jambi: Salim Media Indnesia, 2020, Hlm. 44. 
satu pemerintah provinsi atau satu pemerintah kabupten/kota. Sedangkan saham pada persero/perseroda minimal saham yang dimiliki adalah $51 \%$ (lima puluh satu persen) oleh pemerintah pusat atau satu pemerintah daerah.

Suatu perusahaan untuk mengembangkan atau melakukan ekspansi usaha salah satu caranya adalah menggunakan atau mendirikan anak perusahaan. Hal ini dimaksudkan agar kegiatan inti perusahaan tidak terganggu dan tetap fokus. Badan Usaha Milik Pemerintah dapat dimungkinkan mendirikan anak perusahaan sebagaimana tercantum dalam Pasal 14 Ayat (3) Undang-Undang No 19 Tahun 2003 tentang Badan Usaha Milik Daerah dan Pasal 3 Ayat (4) Peraturan Pemerintah No 54 Tahun 2017 tentang Badan Usaha Milik Daerah. Penelitian ini berfokus pada anak perusahaan yang dimiliki oleh Badan Usaha Milik Daerah.

Terbentuknya induk dan anak perusahaan menyebabkan permasalahan hukum baru karena tidak disertai perkembangan peraturan mengenai bentuk perusahaan khususnya yang berbentuk perseroan. Pengaturan perusahaan induk masih terikat dengan aturan dasar dalam Kitab Undang-Undang Hukum Dagang dan peraturan perundangundangan lain terkait perusahaan baik berbadan hukum maupun bukan badan hukum yang ditujukan untuk mengatur perseroan tunggal, sehingga saat ini antara induk dan anak perusahaan masih dianggap sebagai entitas mandiri yang terpisah satu dan lainnya.

Hubungan hukum yang timbul antara perusahaan induk dengan anak perusahaan merupakan hubungan antara pemegang saham dengan perusahaan. Hubungan hukum tersebut diatur secara jelas dalam anggaran dasar dan anggaran rumah tangga sesuai ketentuan yang berlaku. Induk perusahaan juga memiliki anggaran dasar dan anggaran rumah tangga sebagaimana layaknya Perseroan Terbatas biasa. Dengan demikian induk perusahaan berperan sebagai pengawas terhadap anak perusahaannya sebatas pemegang saham yang diatur dalam anggaran dasar dan anggaran rumah tangga.

Saham anak perusahaan Badan Usaha Milik Daerah berasal dari saham Badan Usaha Milik Daerah dan juga milik publik. Namun masih belum jelas sebenarnya anak perusahaan Badan Usaha Milik Daerah ini status hukumnya milik siapa, apakah kepemilikan anak perusahaan Badan Usaha Milik Daerah dimiliki oleh satu pemerintah daerah. Hal ini menjadi penting untuk dibahas lebih jauh karena adanya perbedaan tanggungjawab hukum antara perseroan terbatas sebagai Badan Usaha Milik Daerah dan perseroan terbatas sebagai milik swasta.

Salah satu dampak dari pentingnya pemisahan yang jelas tersebut adalah pada pelaksanaan kewenangan Badan Pemeriksa Keuangan yang mengacu pada Pasal 6 Ayat (1) Undang-Undang No 15 Tahun 2006 tentang Badan Pemeriksa Keuangan yaitu BPK bertugas memeriksa pengelolaan dan tanggungjawab keuangan negara yang dilakukan oleh Pemerintah Pusat, Pemerintah Daerah, Lembaga Negara Lainnya, Bank Indonesia, Badan Usaha Milik Negara, Badan Layanan Umum, Badan Usaha Milik Daerah dan lembaga atau badan lain yang mengelola keuangan negara.

Berdasarkan hal tersebut di atas, maka penelitian ini akan mengkaji hal-hal sebagai berikut: (1) Bagaimana status hukum kepemilikan anak perusahaan Badan Usaha Milik Daerah? Dan (2) Bagaimana tanggungjawab perusahaan induk Badan Usaha Milik Daerah terhadap anak perusahaannya?

\section{METODE}

Untuk membahas perumusan masalah di atas dan agar dapat dipertanggungjawabkan secara ilmiah, maka penelitian ini menggunakan metode penelitian hukum normatif (metode kepustakaan). Penelitian hukum normatif hanya mengelola dan menggunakan data-data sekunder terkait dengan kedudukan hukum anak perusahaanBadan Usaha Milik Daerah. Bahan hukum sekunder adalah semua dokumen informasi atau hasil kajian seperti jurnal hukum, koran-koran serta tulisan ilmiah terkait pokok pembahasan.yang diteliti.

\section{HASIL DAN PEMBAHASAN}

\section{Status Hukum Kepemilikan Anak Perusahaan Badan Usaha Milik Daerah.}

Perusahaan milik pemerintah daerah dalam perkembangannya tidak hanya terjadi di Indonesia, tetapi terjadi juga di berbagai negara seperti Cekoslovakia, Polandia, Filipina dan sebagainya. ${ }^{2}$ Definisi daerah pada penelitian ini merujuk pada pengertian sebagai bagian lebih kecil dari negara yang penyebutannya berbeda-beda tergantung dari sistem pembagian wilayah yang digunakan negara tersebut.Di Indonesia perusahaan milik pemerintah daerah di sebut dengan Badan Usaha Milik Daerah yaitu badan usaha yang seluruh atau sebagian besar modalnya dimiliki oleh Daerah. $^{3}$

Badan Usaha Milik Daerah dengan definisi tersebut di atas, mengandung arti bahwa perusahaan Badan Usaha Milik Daerah adalah perusahaan yang sebagian besar atau seluruh sahamnya dimiliki oleh Daerah melalui penyertaan secara langsung. Namun, antara daerah sebagai pemegang saham dan perusahaan Badan Usaha Milik Daerah merupakan entitas terpisah. Definisi entitas terpisah adalah kesatuan usaha terpisah yang berdasarkan Entity Theory

${ }^{2}$ Lihat: Yudho Taruno Muryanto, Tata Kelola BUMD: Konsep, Kebijakan dan Penerapan, Malang: Instrans Publishing, 2017, hlm. 15. Lihat juga: Sigit Somadiyono, Op.Cit., hlm. 45-46.

${ }^{3}$ Pasal 1 angka 1 Peraturan Pemerintah Republik Indonesia Nomor 54 Tahun 2017 
(Teori Entitas) memandang perusahaan sebagai sesuatu yang berbeda dan terpisah dari para pihak pemegang saham dan/atau pemiliknya. ${ }^{4}$

Prinsip tersebut memberikan perlindungan kepada pemilik perusahaan dan/atau pemegang saham atas segala tindakan, perbuatan dan kegiatan perusahaan khususnya pada perusahaan berbentuk perseroan terbatas. Berlakunya Perseroan Terbatas sebagai entitas terpisah adalah sejak perseroan mendapatkan Keputusan Pengesahan dari Menteri Hukum dan HAM. ${ }^{5}$

Pemisahan entitas pada perseroan terbatas melahirkan prinsip tanggungjawab terbatas pemegang saham. Pemisahan enitas perseroan terbats diatur dalam Pasal 3 Ayat (1) Undang-Undang Nomor 40 Tahun 2007 tentang Perseroan Terbatas yang menyebutkan bahwa Pemegang saham Perseroan tidak bertanggungjawab secara pribadi atas perikatan yang dibuat atas nama perseroan dan tidak bertanggungjawab atas kerugian Perseroan melebihi saham yang dimilikinya. Apabila menggunakan teori entitas terpisah serta dari definisi Badan Usaha Milik Daerah berdasarkan peraturan perundang-undangan, maka Badan Usaha Milik Daerah modalnya berasal dari Pemerintah Daerah, namun kekayaan tersebut merupakan kekayaan Badan Usaha Milik Daerah, karena Badan Usaha Milik Daerah dan Pemerintah Daerah merupakan entitas yang terpisah.

Perkembangan bisnis di era 4.0 semakin pesat dan luas, apabila suatu entitas bisnis tidak tanggap dalam menghadapi perkembangannya maka dipastikan akan tertinggal atau kalah atau musti mengakhiri bisnisnya. Salah satu entitas bisnis yang paling banyak digunakan adalah perseroan terbatas yang memperluas bidang usahanya dengan cara pemisahan beberapa bidang usaha dalam beberapa perseroan atau sering disebut dengan anak perusahaan. Hal tersebut menjadi alternatif yang dapat dilakukan oleh perseroan terbatas untuk melakukan efisiensi usaha dan menekan ongkos operasi disamping untuk mengejar keuntungan maksimal. ${ }^{6}$

Pemisahan perseroan induk menjadi beberapa anak perseroan memungkinkan masing perseroan untuk fokus dan terarah serta mengurangi risiko pada perseroan induk akibat beragamnya jenis usaha yang dilakukan. Definisi Pemisahan apabila merujuk pada Undang-Undang Nomor 40 Tahun 2007 tentang Perseroan Terbatas di Pasal 1 angka 12 adalah perbuatan hukum yang dilakukan oleh Perseroan untuk memisahkan usaha yang mengakibatkan seluruh aktiva dan pasiva Perseroan beralih karena hukum kepada 2 (dua) Perseroan atau lebih atau sebagian aktiva dan pasiva Perseroan beralih karena hukum kepada 1 (satu) Perseroan atau lebih.

Pasal 135 Undang-Undang Nomor 40 Tahun 2007 tentang perseroan terbatas membagi cara pemisahan menjadi 2 (dua) cara, yaitu (1) Pemisahan murni adalah jenis pemisahan, yang mengakibatkan pengalihan semua aset dan kewajiban perusahaan kepada orang lain karena hukum Dua (dua) perusahaan atau lebih yang menerima pengalihan, dan perusahaan yang telah menghentikan divisinya karena alasan hukum; (2) Pemisahan yang tidak murni mengacu pada pengalihan sebagian aset dan kewajiban perusahaan kepada satu atau Lebih dari satu perusahaan lain, dan perusahaan yang dipisahkan masih ada..

Kesamaan antara dua pemisahan ini adalah pengalihan aktiva dari aset dan kewajiban perusahaan yang dipisahkan. Pada saat yang sama, perbedaannya adalah ada perusahaan yang berpisah setelah pemisahan, sedangkan dalam pemisahan murni, perusahaan yang berpisah tersebut diakhiri karena hukum. Pada saat yang sama, karantina yang tidak tepat dari perusahaan yang dipisahkan belum berakhir. Pengunduran diri perusahaan harus memperhatikan (1) kepentingan perusahaan, pemegang saham minoritas dan karyawan perusahaan; (2) kreditor dan mitra bisnis lainnya; (3) persaingan yang sehat antara masyarakat dan perusahaan. ${ }^{7}$

Berdasarkan prinsipseparated entity ini juga memberikan garis pemisah antara induk dan anak perusahaan. Ketika suatu Perseroan membentuk anak Perseroan maka penyertaan modalnya berasal dari kekayaan induk Perseroan bukan dari pemegang saham dari induk Perseroan. Hal tersebut berdampak terhadap pada perbedaan pertanggungjawaban antara induk Perseroan dan anak Perseroan. Pertanggungjawaban yang dimaksud adalah kepada siapa Perseroan tersebut mempertanggungjawabkan segala kegiatan usahanya.

Hubungan hukum yang timbul antara induk perusahaan dengan anak perusahaan merupakan hubungan antara pemegang saham dengan perusahaan. Keikutsertaan induk perusahaan adalah ikut bertanggungjawab terhadap kerugian anak perusahaan apabila terdapat dominasi induk perusahaan yang mengakibatkan perbuatan melawan hukum atau wanprestasi dan terbukti adanya kerugian dari pihak ketiga. ${ }^{8}$ Dominasi terjadi disebabkan Semakin besar saham yang dimiliki satu entitas dalam perusahaan maka semakin besar pula pengaruh entitas tersebut terhadap

${ }^{4}$ Ide utama dari teori entitas adalah memahami perusahaan sebagai bentuk yang terpisah dari pemiliknya. Teori ini muncul dengan maksud untuk mengrangi kelemahan-kelemahan yang ada dalam proprietary theory dimana pemilik menjadi pusat perhatian. Namun demikian entity theory pada dasarnya tidak berbeda jauh dengan proprietary theory. Lihat: Iwan Triyowono, Sinergi Oposisi Biner: Formulasi Dasar Laporan Keuangan Syari'ah, Iqtishad, Vol 4 No. 1 Marer 2003, 2013 , hlm. 80.

${ }^{5}$ Lihat: Pasal 9 Ayat (1) Undang-Undang Nomor 40 Tahun 2007 tentang Perseroan Terbatas.

${ }^{6}$ Ridwan Khairandy, Hukum Perseroan Terbatas, Yogyakarta: FH UII Press, 2014, hlm. 2.

${ }^{7}$ Lihat : Pasal 126 Ayat (1) Undang-Undang Nomor 40 Tahun 2007 tentang Perseroan Terbatas.

${ }^{8}$ Lihat: Pasal 3 Ayat (2) Undang-Undang Nomor 40 Tahun 2007 tentang Perseroan Terbatas. 
kebijakan perusahaan sehingga semakin tidak indepedent/mandiriperusahaan tersebut. ${ }^{9}$ Tanggung jawab perusahaan induk kepada anak perusahaan dapat berupa tanggung jawab pribadi, tanggung jawab bersama, dan tingkat tanggung jawab tertentu.

Anak perusahaan yang muncul sebagai perseroan terbatas akibat proses merger sudah berstatus badan hukum independen sejak awal, karena anak perusahaan tersebut sudah ada dan berada pada posisi yang sama dengan induk perusahaan sebelum merger. Sebelum dan sesudah penggabungan, anak perusahaan memiliki hak dan kewajiban yang sama, serta memiliki aset independen yang terpisah dari pemegang saham.

Putusan Mahkamah Konstitusi Nomor 48 dan 62/PUU-XI/2013 tanggal 18 September 2014 merupakan momentum atas status kekayaan negara atau daerah yang bersumber dari keuangan negara dan dipisahkan dari Anggaran Pendapatan dan Belanja Negara/Daerah untuk disertakan menjadi penyertaan modal di Badan Usaha Milik Negara/Daerah tetap termasuk dalam keuangan negara. Hal tersebut telah mengakhiri perdebatan mengenai Pasal 2 Huruf g Undang-Undang Nomor 17 Tahun 2003 tentang keuangan negara terkait dengan kekayaan yang dipisahkan pada perusahaan negara/perusahaan daerah.

Perdebatan tentang mana saja yang termasuk dengan keuangan negara/daerah terjadi karena adanya teori otonomi badan hukum privat dan teori transformasi keuangan negara. Kedua teori tersebut menyatakan dengan dimasukkannya keuangan negara yang bersumber dari Anggaran Pendapatan dan Belanja Negara/Daerah ke dalam suatu perseroan terbatas maka status keuangan negara tersebut berubah dari yang tunduk terhadap hukum keuangan publik yaitu Undang-Undang Nomor 17 Tahun 2003 menjadi menundukkan diri terhadap ketentuan keuangan privat yaitu Undang-Undang Nomor 40 Tahun 2007 tentang Perseroan Terbatas serta Peraturan Pemerintah Nomor 54 Tahun 2017 tentang Badan Usaha Milik Daerah.

Pandangan ini mengabaikan terkait pengawasan terhadap penggunaan keuangan negara dari Anggaran Pendapatan dan Belanja Daerah yang disertakan sebagai modal/saham dalam Badan Usaha Milik Daerah hanya dilakukan khusus terhadap aliran keuanggan negara/daerah. Negara/daerah berkepentingan untuk mengamankan uang negara/daerah yang masuk dalam kas Badan Usaha Milik Daerah melalui mekanisme penyertaan modal ataupun subsidi. Dalam teori hukum keuangan negara, eksistensi asas kelengkapan telah menjamin tidak adanya wilayah abuabu yang memungkinkan adanya aliran keuangan negara yang lepas dari sistem pengawasan Dewan Perwakilan Rakyat-Daerah melalui audit Badan Pemeriksa Keuangan Republik Indonesia. Prinsip hak preferensi negara dimana negara/daerah tidak boleh kehilangan kewenangan melakukan pengawaan terhadap penggunaan keuangan negara yang harus dipertanggungjawabkan melalui siklus pengelolaan Anggaran Pendapatan dan Belanja Negara/Daerah.

Hal tersebut sekaligus memperkuat teori sumber yang merupakan teori klasik dalam pengelolaan keuangan negara. Teori sumber berprinsip setiap aliran uang negara/daerah yang bersumber dari Anggaran Pendapatan dan Belanja Negara/Daerah harus dipertanggungjawabkan berdasarkan mekanisme peraturan perundang-undangan terkait Anggaran Pendapatan dan Belanja Negara/Daerah. Di satu sisi, pengelolaan Badan Usaha Milik Daerah harus diperuntukan untuk kesejahteraan sebagaimana diatur dalam Pasal 33 Undang-Undang Dasar 1945. Oleh sebab itu, selayaknya pengelolaan Badan Usaha Milik Daerah dan anak perusahaannya tetap berfokus mewujudkan kesejahteraan rakyat dan daerah dalam hal ini pemerintah daerah tidak kehilangan kendali pengawasan dan tata kelola Badan Usaha Milik Dearah.

Konsep dualisme pemahaman keuangan negara terkait privatisasi Badan Usaha Milik Dearah telah terjadi transformasi atau perubahan bentuk keuangan negara/publik menjadi bentuk uang privat dalam wadah Badan Usaha Milik Dearah berbentuk perseroan terbatas seakan-akan bukan objek pengawasan lembaga negara/daerah. Privatisasi bukanlah alasan untuk melegalkam praktik korupsi dengan dalil sebagai risiko bisnis. Badan Usaha Milik Dearah didirikan oleh daerah bertujuan untuk (1) memberikan manfaat bagi perkembangan perekonomian daerah; (2) menyelenggarakan kemanfaatan umum; dan (3) memperoleh laba dan/atau keuntungan. ${ }^{10}$

Badan Usaha Milik Dearah ketika membentuk atau mendirikan anak perusahaan tidak boleh lepas dari tujuan pendirian Badan Usaha Milik Dearah. Pendirian anak perusahaan tidak memisahkan atau mentransformasi kedudukan penyertaan saham Badan Usaha Milik Dearah sebagai keuangan yang tunduk terhadap ketentuan hukum privat. Sebab maksud dari adanya anak perusahaan adalah untuk membantu mempercepat dan mempermudah tercapainya tujuan dari induk perusahaan yaitu Badan Usaha Milik Daerah. Jadi, selama saham mayoritas (51\%) adalah milik Badan Usaha Milik Daerah, maka anak perusahaan yang berbentuk perseroan adalah milik daerah dan wajib tunduk terhadap peraturan perundang-undangan terkait Badan Usaha Milik Daerah dan keuangan negara/daerah. Tetapi kedudukan hukum anak perusahaan tersebut bukanlah Badan Usaha Milik Daerah dan tetap sebagai perseroan privat atau swasta.

\footnotetext{
${ }^{9}$ Pengaruh pemegang saham mayoritas oleh salah satu Pemerintah Daerah pada Bank Pembangunan Daerah sangat kuat dalam menentukan arah kebijakan dan tidak menutup kemungkinan untuk menentukan kebijakan perusahaan dari yang paling kecil sampai tingkat direktur dan komisaris. Sigit Somadiyono, Op.Cit, hlm. 180.

${ }^{10}$ Pasal 7 Peraturan Pemerintah Nomor 54 Tahun 2017 tentang Badan Usaha Milik Daerah.
} 


\section{Tanggungjawab Perusahaan Induk Badan Usaha Milik Daerah Terhadap Anak Perusahaannya.}

Undang-Undang Nomor 40 Tahun 2007 tentang Perseroan Terbatas mengatur tanggungjawab terbatas (limit liability) untuk para pemegang saham perseroan, namun menjadi menarik apabila perusahaan yang menjadi induknya adalah Badan Usaha Milik Daerah. Hal yang menarik adalah dilihat dari konstruksi Badan Usaha Milik Daerah sebagai badan hukum yang sebagian atau seluruhnya milik pemerintah daerah. Anak perusahaan adalah perusahaan yang sebagian besar sahamnya dimiliki oleh Badan Usaha Milik Daerah bukan dimiliki oleh pemerintah secara langsung.

Perseroan Terbatas merupakan badan hukum berdasarkan Pasal 1 angka 1 Undang-Undang Nomor 40 Tahun 2007 tentang Perseroan Terbatas. Perseroan Terbatas menjadi subjek hukum yang mempunyai hak dan kewajiban serta memiliki kedudukan yang mandiri yang terpisah dari para pemegang sahamnya. Dalam Perseroan Terbatas hanya organ yang dapat mewakili Perseroan dalam menjalankan perusahaan. Perseroan Terbatas dapat melakukan perbuatan hukum seperti manusia yang telah cakap hukum dan juga dapat memiliki kekayaan atau hutang.

Dengan adanya harta kekayaan yang terpisah mengandung arti apabila dikemudian hari timbul permasalahan berkibat munculnya kewajiban hukum terhadap perseroan maka tanggungjawab harta kekayaan para pemegang saham hanya terbatas pada saham yang ada pada perseroan tersebut. Prinsip ini disebut prinsip tanggungjawab terbatas yang mentapkan bahwa para pemegangn saham perseroan terbatas tidak bertanggungjawab secara pribadi atas perbuatan hukum atas nama perseroan dan tidak bertanggungjawab atas kerugian perseroan melebihi nilai saham yang telah diambilnya. Tanggunjawab terbatas ini diatur didalam Pasal 3 Ayat (1) Undang-Undang Nomor 40 Tahun 2007 tentang Perseroan Terbatas.

Undang-Undang Nomor 40 Tahun 2007 tentang Perseroan Terbatas tidak mengatur terkait induk perusahaan dan/atau sebab munculnya anak perusahaan. Pengertian induk dan anak perusahaan diambil dari para ahli maupun dari literatur-literatur yang ada. Anak perusahaan adalah perusahaan yang sepenuhnya atau lebih dari separuh sahamnya dimiliki oleh perusahaan lain atau disebut juga perusahaan induk. ${ }^{11}$

Definisi perusahaan induk adalah suatu badan usaha yang dalam salah satu tujuan bisninya adalah untuk mentake over atau memiliki saham dalam satu atau lebih perusahaan lain dan/atau mengatur satu atau lebih perusahaan lain tersebut. Induk perusahaan dan anak perusahaan mempunya hubungan subordinasi dimana induk perusahaan membawahi anak perusahaan karena tujuan dari anak perusahaan dibentuk bertujuan memperluas bisnis induk perusahaan. Kategori diatas tidak mutlak karena sebuah perusahaan dapat dikatakan induk perusahaan apabila memiliki saham di perusahaan lain (anak perusahaan). Kepemilikan saham dapat terjadi dikarenakan pembelian saham dari perusahaan yang telah ada atau penyertaan modal pada perusaahaan yang akan didirikan.

Perusahaan swasta dapat berbentuk perusahaan perseorangan, perusahaan persekutuan bukan berbadan hukum serta perusahaan persekutuan berbadan hukum. Sedangkan perusahaan negara berupa Badan Usaha Milik Daerah berbentuk badan hukum. Kesemua bentuk perusahaan tersebut memiliki harta kekayaan yang terpisah dari pemilik atau pemegang sahamnya, perbedaannya hanya pada pertanggungjawabannya dimana perusahaan perorangan dan bukan badan hukum tanggungjawabnya sampai dengan harta pribadi para pemilik sedangkan perusahaan badan hukum terbatas pada modal atau saham pada perusahaan.

Konsekuensi dari Badan Usaha Milik Daerah yang memiliki anak perusahaan adalah induk perusahaan dan anak perusahaan memiliki hak dan kewajiban tersendiri. Hak dan kewajiban perusahaan induk tidak otomatis menjadi hak dan kewajiban anak perusahaan, begitu juga sebaliknya. Perikatan ataupun perbuatan hukum lainnya yang dibuat oleh induk perusahaan tidak mengikat anak perusahanya dan sebaliknya. Keutamaan adanya induk dan anak perusahaan adalah dalam ketersediaan dana dan penjaminan pinjaman dimana induk dan anak perusahaan dapat bersama-sama mengembangkan usaha dengan melakukan subsidi silang dan/atau mengelola dana secara optimal.

Struktur saham Badan Usaha Milik Daerah dimiliki oleh Pemerintah Daerah sehingga pembentukan Badan Usaha Milik Daerah tunduk pada undang-undang terkait badan hukum publik tetapi kegiatannya pengelolaan tunduk dan diatur dalam hukum privat. Karakteristik suatu badan hukum adalah pemisahan harta kekayaan badan hukum dari harta kekayaan pemilik dan pengurusnya. Badan Usaha Milik Daerah merupakan badan hukum yang memiliki kekayaan tersendiri dan terpisah. Kekayaan negara yang dipisahkan secara fisik adalah berbentuk saham yang dipegang oleh pemerintah daerah, bukan harta kekayaan Badan Usaha Milik Daerah tersebut.

Implikasi dari penerapan prinsip limited liability adalah induk perusahaan yang merupakan pemegang saham pada anak perusahaan hanya terlindungi apabila anak perusahaan tersebut tidak dapat menyelesaikan masalah yang dihadapi pihak lain (seperti pemegang saham minoritas / lain, karyawan). Kreditur yang timbul dari pelaksanaan perusahaan atas instruksi perusahaan induk ${ }^{12}$

Piercing the corporate veildapat dikembangkan menjadi prinsip hukum mengenai hubungan antara perusahaan induk dan anak perusahaan untuk menghilangkan kewajiban terbatas perusahaan induk. Isi dasar dari penerapan prinsip-prinsip hukum perseroan adalah bahwa penggabungan anak perusahaan dengan induk perusahaan akan

\footnotetext{
${ }^{11}$ Lihat: http://kamusbisnis.com/arti/anak-perusahaan/ diunduh pada tanggal 21 Februari 2021.

${ }^{12}$ Sulistiowati, Aspek Hukumdan Realitas Bisnis Perusahaan Grup di Indonesia, Jakarta: Erlanmgga, 2010, hlm. 3.
} 
mengakibatkan kemandirian ekonomi anak perusahaan karena kepentingan ekonomis anak perusahaan dimaksudkan untuk mendukung kepentingan komersial dan ekonomi induk. perusahaan. Perusahaan atau perusahaan grup. Oleh karena itu, untuk menghilangkan perseroan terbatas pada induk perusahaan, perlu adanya bukti bahwa pengendalian induk perusahaan terhadap anak perusahaan justru akan mengarah pada kemandirian ekonomi anak perusahaan.Oleh karena itu, anak perusahaan hanya dapat menjadi alat bantu bagi induknya. perusahaan. Perilaku tersebut hanya digunakan untuk melaksanakan instruksi dari perusahaan induk.. ${ }^{13}$

Kekayaan Badan Usaha Milik Daerah terpisah dari kekayaan daerah karena kekayaan daerah didalam Badan Usaha Milik Daerah hanya sebatas saham. Sehingga pada saat ada kerugian yang dialamiBadan Usaha Milik Daerah bukanlah kerugian negara/daerah. Terkait dengan anak perusahaan Badan Usaha Milik Daerah maka tanggungjawab Badan Usaha Milik Daerah hanya sebatas saham yang disetorkan.

\section{SIMPULAN}

a. Anak perusahaan yang dimiliki Badan Usaha Milik Daerah berdasarkan perundang-undangan, teori dan doktrin hukum perseroan merupakan entitas yang mandiri dan tunduk terhadap hukum privat walaupun modalnya berasal dari Badan Usaha Milik Daerah yang bersumber dari Anggaran Pendapatan dan Belanja Daerah. Hal itu dikarenakan hubungan Badan Usaha Milik Daerah dengan anak perusahaannya adalah hubungan antara pemegang saham pada anak perusahaannya.

b. Anak perusahaan Badan Usaha Milik Daerah muncul karena penyertaan modal dari perusahaan induk sehingga Badan Usaha Milik Daerah berkedudukan sebagai pemegang saham. Tanggungjawab Badan Usaha Milik Daerah hanya sebatas saham yang disertakan dalam anak perusahaan atau tanggungjawab lainnya sesuai dengan akta pendirian anak perusahaan tersebut.

\section{Saran}

Berdasarkan penelitian di atas maka perlu dibuat peraturan perundang-undangan tentang kedudukan hukum anak perusahaan serta tanggungjawab induk perusahaan khususnya perusahaan milik daerah sehingga terjadi harmonisasi pengaturan. Dan perlu dilakukan penelitian yang lebih mendalam terkait kedudukan dan tanggungjawab hukum anak perusahaan Badan Usaha Milik Daerah.

\section{DAFTAR PUSTAKA}

Iwan Triyowono, Sinergi Oposisi Biner: Formulasi Dasar Laporan Keuangan Syari'ah, Iqtishad, Vol 4 No. 1 Marer 2003, 2013, hlm. 80.

Ridwan Khairandy, 2014,Hukum Perseroan Terbatas, Yogyakarta: FH UII Press.

Sigit Somadiyono, 2020,Prinsip Kepemilikan dan Kemandirian Badan Usaha Milik Daerah dalam Kaitannya Sebagai Perusahaan Milik Pemerintah, Jambi: Salim Media Indnesia, 2020.

Sulistiowati, 2010,Aspek Hukumdan Realitas Bisnis Perusahaan Grup di Indonesia, Jakarta: Erlanmgga.

Yudho Taruno Muryanto, 2017,Tata Kelola BUMD: Konsep, Kebijakan dan Penerapan, Malang: Instrans Publishing. Undang-Undang Nomor 40 Tahun 2007 tentang Perseroan Terbatas.

Peraturan Pemerintah Republik Indonesia Nomor 54 Tahun 2017.

http://kamusbisnis.com/arti/anak-perusahaan/ 